\title{
Influence of Ground End Mill Surface Quality on Cutting Tool Life
}

Vaclav Schornik, Miroslav Zetek, Tomas Baksa

Faculty of Mechanical Engineering, University of West Bohemia in Pilsen. Univerzitni 8, 30614 Plzen. Czech Republic. E-mail: schornik@rti.zcu.cz, baksa@rti.zcu.cz

Cutting tools made of cemented carbides currently dominate the field of machining. This is due to their outstanding properties and applicability to various materials. However, there are still opportunities for enhancement in the field of cutting tool durability, particularly in the machining of highly resistant super alloys. Grinding critically affects the integrity of the machined surface, which has a significant impact on the durability of cutting tools. Certain cutting conditions and grinding strategies can lead to a sudden failure of the cutting tool in the cut. The main goal of this study is to investigate the influence of the cutting conditions on the end mill flute surface quality and durability of these cutting tools when machining Inconel 718. The surface parameters are described and real machining tests are conducted.

Keywords: Grinding, Electron Microscopy, Cutting Tool Life, Surface, End Mill

\section{Acknowledgements}

The present contribution has been prepared under the project LO1502 'Development of the Regional Technological Institute' under the auspices of the National Sustainability Programme I of the Ministry of Education of the Czech Republic aimed at supporting research, experimental development and innovation.

\section{References}

[1] YANG, J., ODÉN, M., JOHANSSON-JÕESAAR, M.P., LLANES, L. (2014). Grinding Effects on Surface Integrity and Mechanical Strength of WC-Co Cemented Carbides. In: Procedia CIRP, Volume 13, Pages 257-263

[2] JIANG, D., ANNÉ, G., VLEUGELS, J., VANMEENSEL, K., ERAERTS, W., LIU, W., LAUWERS, B., VAN DER BIEST, O. (2005). Residual stresses in hard metals caused by grinding and EDM machining and their influence on the flexural strength. In: Powder Metallurgical High Performance Materials, Volume 2, p. 1075, Austria.

[3] HEGEMAN, J.B.J.W, DE HOSSON, J. Th. M, DE WITH, G. (2001) Grinding of WC-Co hard metals. In: Wear, Volume 248, Issues 1-2, Pages 187-196.

[4] UHLMANN, E., HÜ BERT, C. (2011). Tool grinding of end mill cutting tools made from high performance ceramics and cemented carbides. In: CIRP Annals - Manufacturing Technology, Volume 60, Issue 1, Pages 359362.

[5] ISHIDA, T., MORIGUCHI, H., IKEGAYA, A. (2011) Development of Cemented Carbide Tool of Reduced Rare Metal Usage. In: Industrial Materials, Sei Technical Review, Number 73.

[6] DENKENA, B., UHLMANN, E., SCHRÖER, N. (2015) Advances in Tool Grinding and Development of End Mills for Machining of Fibre Reinforced Plastics. In: Procedia CIRP, Volume 35, Pages 38-44.

[7] DOBRESCU, T. G., PASCU, N. E., OPRAN, C., BUCURESTEANU, A. M. (2012) Subsurface Damage in Grinding Silicon Ceramics. In: Annals of DAAAM for 2012 \& Proceedings of the 23rd International DAAAM Symposium, Volume 23, No.1, pp. 0121-0124, Vienna

[8] FRITSCHE, A., BLEICHER F. (2015) Experimental Investigation of the Heat Flux Distribution in Grinding of Titanium Alloy. In: Procedia Engineering, Volume 100, 2015, Pages 987-993, ISSN 1877-7058

[9] PETRU, J., SCHIFFNER, J., ZLAMAL, T., SADILEK, M., STANCEKOVA, D. (2015). Investigations of cutting tool wear while machining Inconel 718. In: Manufacturing Technology, 15 (3), pp. 396-403.

[10] TOMÍČEK, J., MOLOTOVNIK, A. (2016). Influence of Cutting Conditions on Profile Milling of INCONEL 738LC Alloy. In: Manufacturing Technology, 16 (2), pp. 461-467.

[11] GRABCHENKO, A., FEDOROVICH, V., PYZHOV, I., KUNDRÁK, J. (2014). 3D Simulation of Vibrating Diamond Grinding. In: Manufacturing Technology, 14 (2), pp. 153-160.

[12] MIČÚCH, M., ČILLIKOVÁ, M., NESLUŠAN, M., MIČETOVÁ, A. (2014). Influence of Cutting Conditions and Grinding Wheel Wear on Barkhausen noise of ground surfaces. In: Manufacturing Technology, 14 (1), pp. 66-71. 